\title{
Open spaces increase the quality of built up areas
}

\author{
K. Lestan ${ }^{1}$, M. Golobič ${ }^{1,2}$, I. Eržen ${ }^{3,4}$ \& B. Goličnik Marušić ${ }^{1}$ \\ ${ }^{1}$ Urban Planning Institute of the Republic of Slovenia, Slovenia \\ ${ }^{2}$ Department of Landscape Architecture, Biotechnical Faculty, \\ University of Ljubljana, Slovenia \\ ${ }^{3}$ National Institute of Public Health, Slovenia \\ ${ }^{4}$ Medical Faculty, University of Ljubljana, Slovenia
}

\begin{abstract}
Spatial planning in Slovenia was significantly influenced by the political and economic changes in the beginning of 1990s. The switch to open market economy caused a rather substantial negligence of common interests and communal values. A new paradigm of values immerged in physical space mostly through the actions of investors. This paper examines the problem in the context of new collective housing complexes built in Ljubljana, which, in comparison to the older residential estates, demonstrate a much higher building density, and a lot lower quality and quantity of adjacent open spaces. Green areas are essential for increasing life quality of all residents, especially children and the elderly, who depend on the proximity of well-designed open spaces in their living surroundings. Our research explores how size and equipment of open spaces influence the ways in which they are used. Qualitative and quantitative analyses of open space design in residential estates, performed by evaluating selected urban design indicators, have been followed by an experimental method of observations and behavioural mapping in open spaces within a selected residential estate.

Keywords: residential estate, housing complex, quality of life, vulnerable user groups, health, planning, urban green areas.
\end{abstract}

\section{Theoretical background and research framework}

Ljubljana, the Slovenian capital is a city of 270,000 inhabitants, where nature and urban tissue are interwoven. Despite the close connection with its natural 
background, the significance of green areas within the city itself for life quality remains and even increases with time. The main question of the research addresses the issue of children and elderly living in residential areas, who are directly dependent of the proximity of green open areas (Simoneti et al. [1], Ward Thompson and Travlou [2]). From the aspect of most vulnerable users, local green areas cannot be substituted by green areas in other parts of the city.

With the changes of historical periods of urbanism, the concept of residential housing has changed, and the one we use today differs from its original form. Therefore this paper separates the concept of residential estates in their true, original form as developed from 1960 to 1980, from the recently established concept of a new housing complex. The key difference between residential housing estates and new housing complexes is in their programme: according to recent research, the new collective residential developments neglect their communal open spaces, which should complement the built up structures in the form of green areas. The open areas designs vary between the emptiness of vast paved surfaces and decorative design; while the physical, social and psychological needs, which the users normally meet in the open spaces, are considered as subordinate to fulfilling the need for a new apartment (Simoneti and Vertelj Nar [3]). A comparison with some older residential estates in Ljubljana clearly shows that the older green open areas were significantly better planned. In that period, the concept of a residential estate was clearly structured, and primarily socially oriented. Planners were not faced by the market economy pressure and spatial limitations in planning large-scale projects (Gazvoda [4]). In this manner, the original concept of residential estates was conceived around the idea of building communities, including all accompanying services such as childcare facilities, schools, community centres, shops, communal playgrounds and sports facilities, and also vast open green areas for relaxation and recreation; which is reasonable because of the fact, that the first residential estates were planned to house up to 5000 residents (Mihelič [5]). Approximately half of the population of Ljubljana now resides in housing estates built in that period of time (Rebernik [6]).

Apartment block developments provide accommodation for a dense population in cities. According to the World Health Organisation, more than half of the World's population live in urban areas (WHO [7]). Along with the changed way of life which constrains people indoors most of their time, an increasing number of recent epidemiological health research studies focus on how indoor pollutants affect human health. Sources of indoor air pollution are external air, materials and furnishing, as well as people and their activities. Especially modern materials used in contemporary buildings cause the majority of health risks (Philomena [8]). The symptoms related to staying indoors are headache, dizziness, sore eyes, difficulties with breathing, etc, identified by the World Health Organisation as the 'Sick Building Syndrome'.

The syndrome [9] is clinically difficult to diagnose and includes the body's reaction to a momentary discomfort, while the symptoms disappear relatively soon after leaving the room. The modern way of life, which does not leave much time to spend outdoors and does not provide appropriate open areas to fulfil 
one's needs of the outdoors, can be a health hazard in the long term time scale, and can lead to chronic diseases. Non-contagious chronic diseases are the key healthcare burden in Slovenia as well as in other developed societies and present an immense negative effect on a country's social and economic development (Artnik et al. [10]).

On one hand there is therefore the fact that human urban health requires spending time outdoors, while on the other hand the contemporary professional paradigms of spatial planning [11] dictate urban regeneration, densification and internal development. The aim of the investors to maximise the amount of profitable, therefore built-up areas, may cause these paradigms to be interpreted in a way that reduces the size and the quality of open green areas to the minimum, or even eliminates them altogether. Professionals working in the field of residential housing in Slovenia [12] argue that appropriate open areas are mostly missing from new collective residential developments. High density development, achieved at the cost of open space must be questioned, and the profits should be balanced by related health costs, which can rise in low quality living environment. The main reason that these costs are not adequately considered is that it is much easier to calculate the profits from a newly built development in the near future than it is to assess the long term health risks of living in high density areas. When high density residential areas are connected with some other causative factors such as, e.g. social housing estates, there is a possibility of generating other determinants that cause an unhealthy lifestyle, e.g. the profile of low education population, economically disadvantaged residents, etc (Dimitrovska Andrews [13], Zaletelj-Kragelj et al. [14]).

The interdisciplinary approach of the research regarding the significance of urban green space for the health of urban population in the case of residential estates in Ljubljana combines the field of planning with public health science. Hygiene, as part of public health, is the foundation of urbanism. For the purpose of the study, the issue of public health is focussed on lifestyles and how they relate to general health. It is assumed that poor quality of urban furniture and the lack of open green areas lead to limited forms of spatial uses and consequently to a less healthy lifestyle, while residential areas with larger open areas which offer a wider range of activities result in a more diverse spatial use, and therefore encourage a healthier lifestyle. Since it is not possible to discuss any health implications directly caused by the lack of access to open and green areas (Zaletelj-Kragelj et al. [14]), we use the behavioural style of residents as an indicator of health risks within the framework of public health. The research part of the study therefore explores the connections between open space quality and the behavioural patterns of residents, related to spending time outdoors. The study addresses the scope of open areas and the ways in which they are used, and last but not least, the feedback of local residents and their personal opinions are explored in more detail. 


\section{Research methodology regarding the quality of open spaces in residential areas}

At the beginning of the study, eight residential areas in Ljubljana were selected; four of which are more recent developments (Nova Grbina, Viška Sončava, Celovški Dvori in Mesarska), and the other four belong to the older generation of residential estates (VS4 - Bonifacija, BS3 v Bežigradu, ŠS6 v Šiški in Trnovska Soseska VS1). The research is limited to residential areas in Ljubljana in order to achieve a homogeneous context of macro-locational parameters. The residents of Ljubljana have the access to similar services and to large green open areas of the same quality. The selected residential estates and housing complexes were described and evaluated according to three different aspects of urban development (spatial, demographical and socio-economic), as all three groups of criteria are closely related to lifestyles, which can be beneficial or harming to general health. The spatial group includes the physical characteristics of the residential area, the availability of services and facilities, the open green areas and their accessibility. The demographic criteria include the age structure of the residents, while the socio-economic criteria are the employment status and the level of education. Each criterion was allocated a set of indicators, evaluated individually for each residential area. The obtained descriptions of residential areas were used for the selection of areas for further study. Since the focus of the research is in evaluating new housing complexes we included all four into the further study. VS 4, Bonifacija was assessed as the most appropriate example from the group of older residential estates, since it is most comparable in size, population and type of buildings. It was therefore included in further study as a comparison.

The second step of the research involved the method of observations and behavioural mapping. It is one of the most commonly used methods of studying urban public open spaces. Behavioural map is the final product of recording behaviour in space, and environmental psychology defines several types of behavioural maps; they can be behavioural matrices or maps in the true sense of the word. Spatial behaviour is normally observed within a limited time interval, so the results represent a segment of the actual life of a certain place (Goličnik and Ward Thompson [15]). The observed activities were selected according to two criteria: what can happen in this place (related to the size of the observed area and the available equipment allowing different uses), and what is the behavioural lifestyle of the residents (related to the public health science). For the purpose of this research, both behavioural matrices and maps were used; the first ones serve as a quantitative description tool of individual activities, while the latter show the correlation between spatial structure and its uses. Before the beginning of fieldwork research, a coding system was defined; that is a set of symbols, used to record a specific activity. A schedule was set with three time periods of the day (from $10 \mathrm{am}$ to 12 noon, from $1 \mathrm{pm}$ to $3 \mathrm{pm}$, and from $5 \mathrm{pm}$ to $7 \mathrm{pm})$. Prior to the fieldwork, the selected residential areas were divided into subareas, defined as observation units, which can be monitored within one sight of the observer. Every subarea was then observed ten minutes within each time 
period. Ten days of observations were performed within three weeks in September 2012; including weekends. All shortlisted residential areas were observed at the same time, so the results show a comparative section of time and space.

The field work observations were followed by data transfer into a digital Geographical Information System (GIS), including the crucial action of database formation, which served as the key data analysis tool. The database was used to rank classified parameter categories into classes, which allowed further data manipulation, comparison between cases and graphically presenting the observed activities according to chosen categories. Every data input of an observed activity of one single person is described with parameters within the following categories: sex, activity, type of activity, category of activity, age, duration, time of day, part of the week, temperature, wind, air humidity, clear or overcast sky, and date. 'Activity' is a descriptive category, which explains the action in more detail, while the 'Type of Activity' assigns the detailed description to the nearest class, e.g. walking, playing, child care, spending time outdoors, etc. The 'Category of Activity' ranks all different activities observed during the field research, into one of four classes on an even more abstract level: 'passive in space', 'active in transit', active in space', 'momentarily passive, otherwise in transit'. The category 'Duration' labels only the activities in space, which are not transitory, and the 'Time of Day' relates to one of the three daily time periods of observations. The remaining listed categories offer an insight into the current external conditions during the time of observations, which might affect the results of recorded activities and the overall use of the space.

\section{Results and discussion}

The results of urban design indicators analysis (Table 1) clearly show the differences between the new and the old housing estates regarding surface areas. All new estates are on average half the size of the reference residential estate (VS4) or smaller; despite the fact that this particular estate was the smallest of selected case study sites, included in the first phase of the methodology. This shows that new housing sites sizes have been reduced from the start, compared to the planning economy period when residential estates in the true meaning of the word were built much more spaciously. On the one hand this affects the aesthetics of residential estates: while the old estates helped shape the image of a city, the new ones were expected to maintain that image and even enhance it. At this point it has to be noted that the new housing estates are developed inwards [16], which includes urban regeneration and densification, preserving agricultural land and landscape character intact. Such limited offer of land increases its value, which pushes investors to make maximum use of space; as unfortunately the justification for new developments are predominantly measured by their profits. Apart from bringing certain benefits, the current urban development therefore creates certain dilemmas; e.g. how to locate new developments within an existing urban tissue without decreasing the aesthetic and functional qualities of the broader urban area, and nonetheless respecting the 
developers' legitimate expectations of cost-effective investments (Dimitrovska Andrews [13]).

The profit of an investment is directly correlated with how well the site is used, meaning that increased built-up area density increases the amount of properties that can be put on the market. The Floor Space Index (FSI) is higher in the case of all new housing complexes, when compared to the older residential estate VS4. The recommended FSI values normally depend on the amount of building levels. Apart from the recommendations found in literature, the FSI and site ratio (ratio of a building's total floor area to the size of the plot) are mentioned in the 'Spatial Planning Regulations of the Republic of Slovenia' (in Slovene: 'Uredba o prostorskem redu Slovenije'; transl. note), which states that purely residential areas should adopt the value of site ratio of 0.4 and the value of FSI of 1.2 [17]. According to this regulation, all five selected residential areas listed in Table 1 respect the site ratio recommendation; while the FSI value is exceeded in the case of housing estates Celovški Dvori and Mesarska. In the process of spatial planning however, the so called 'Implementation Conditions' (in Slovene: 'Prostorsko Izvedbeni Pogoji'; transl. note) are followed as priority conditions, and those are specific to each site individually, according to its characteristics and location. The new housing complexes respect both the FSI and site ratio of the relevant 'Implementation Conditions' effective at the time of acquiring the building permission, which allow higher values of both indexes than recommended. In general it can be concluded, that new estates adopt a higher FSI when compared to the older ones, and that consequentially means a higher number of residents will live there. This is closely related to a higher demand of open spaces within the residential area, most obviously noted in the case of Celovški Dvori. The above stated also implies that following the FSI and site ratio values, an appropriate amount of open spaces is not necessarily provided.

The building density data matches findings related to the total area of children's playgrounds and sports facilities within a residential area. Looking at numerical data it can be concluded, that a higher built-to-open space site ratio is achieved by reducing the size of playgrounds, open spaces and green areas. The surface areas of children's playgrounds are inadequate in all studied cases; the closest to the standards is Nova Grbina residential area. In the case of children's playgrounds and sports facilities, an even more eloquent fact is the ratio between the total surface of playground and recreational areas and the number of residents. In the case of Celovški Dvori, this ratio is very low; however these areas include sports facilities, which is not the case in any other housing complex included in the study. The lowest recorded ratio between playgrounds, including recreational areas and the number of residents, is in the case of Mesarska estate, showing the smallest surface area per resident. This fact raises concerns, especially when considering that all properties of the estate are not fully inhabited yet. The residential estate VS4 demonstrates a good example even in the case of the indicator concerning the quality and quantity of playgrounds and recreational areas. Apart from that, the case of VS4 estate includes a number of open spaces with a higher 'experiential value' offering additional play 
Table 1: $\quad$ The values of spatial criteria indicators, collected for the residential areas Nova Grbina, Viška Sončava, Celovški Dvori and Mesarska compared to VS-4 or Bonifacija.

\begin{tabular}{|c|c|c|c|c|c|c|}
\hline \multirow{9}{*}{  } & & \multirow{3}{*}{\begin{tabular}{|c|} 
TYPE OF \\
MEASUREMENT \\
$\mathrm{m}^{2}$
\end{tabular}} & NOVA GRBINA & VIŠKA SONČAVA & VS4 - BONIFACIJA & \multirow[b]{2}{*}{$\begin{array}{c}\text { REFERENCE } \\
\text { VALUE }\end{array}$} \\
\hline & INDICATOR & & \multicolumn{3}{|c|}{ VALUE } & \\
\hline & surface area & & $30.700,1(8)$ & $20.443,54(8)$ & $83.744,53(8)$ & comparison \\
\hline & $\begin{array}{l}\text { number of all residential } \\
\text { units }\end{array}$ & number & $316^{*}$ & $248^{*}$ & $904 *$ & comparison \\
\hline & $\begin{array}{l}\text { number of occupied } \\
\text { apartments }\end{array}$ & number & $241 *$ & $132 *$ & $759 *$ & comparison \\
\hline & number of residents & number & $543^{*}$ & $342^{*}$ & $1613^{*}$ & comparison \\
\hline & building height & $\begin{array}{l}\text { gf }+x \text { (ground floor } \\
+x \text { floors }+ \\
\text { mansard) }\end{array}$ & $\begin{array}{c}\text { from } g f+1+M \text { to } g f \\
+3+M(6,7)\end{array}$ & $g f+4+T(10)$ & $g f+4, g f+10(T)$ & comparison \\
\hline & FSI- floor space index & $\begin{array}{l}\text { gross floor surface } \\
\text { area/ site surface } \\
\text { area }\end{array}$ & $1,14(7,8,9)$ & $1,17(9)$ & $0,68(\mathrm{~T}, 8,9)$ & $\begin{array}{l}\text { depending on the } \\
\text { number of floors ( } 3 \text { ) }\end{array}$ \\
\hline & site coverage & $\begin{array}{l}\text { gross groundfloor } \\
\text { surface area/s site } \\
\text { surface area }\end{array}$ & $0,33(7,8,9)$ & $0,41(9)$ & $0,20(\mathrm{~T}, 8,9)$ & comparison \\
\hline \multirow{4}{*}{ 窟 } & grocery shop & $\begin{array}{l}\text { shop/ number of } \\
\text { residents } \\
\text { distance } \mathrm{m}\end{array}$ & $\begin{array}{c}0(\mathrm{~T}) \\
257(8)\end{array}$ & $\begin{array}{c}0(\mathrm{~T}) \\
415(8)\end{array}$ & $\begin{array}{c}1(\mathrm{~T}) \\
0\end{array}$ & $\begin{array}{l}\text { average } \\
\text { average }\end{array}$ \\
\hline & children's playgrounds & $\begin{array}{l}\mathrm{m}^{2} / \text { number of } \\
\text { residents }\end{array}$ & $2,3(9)$ & $1,51(8,9)$ & $1,16(9)$ & $\begin{array}{l}2,4-4,8 \mathrm{~m}^{2} / \text { resident } \\
\text { (1) or } 4,0-13,0 \\
\mathrm{~m}^{2} / \text { resident (3) }\end{array}$ \\
\hline & sports facilities & $\begin{array}{l}\mathrm{m}^{2} / \text { number of } \\
\text { residents }\end{array}$ & $0(\mathrm{~T})$ & $0(\mathrm{~T})$ & $0,41(9)$ & $\begin{array}{l}2,88 \mathrm{~m}^{2} / \text { resident (3) - } \\
3 \mathrm{~m}^{2} / \text { resident (1) }\end{array}$ \\
\hline & car park areas & $\begin{array}{l}\text { number of parking } \\
\text { places/apartment }\end{array}$ & $1,8(7)$ & $1,5(11,9)$ & 0.9 & $\begin{array}{l}1,5 \text { parking spaces/ } \\
\text { apartment ( } 2 \text { ) }\end{array}$ \\
\hline \multirow{6}{*}{ 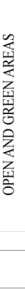 } & all open areas & $\mathrm{m}^{2}$ & $20.669,51(8)$ & $12115,06(8,9)$ & $66946,51(8)$ & comparison \\
\hline & $\begin{array}{l}\text { functional areas } \\
\text { (excluding private } \\
\text { groundfloor atrium } \\
\text { gardens, roads and } \\
\text { external car park areas) }\end{array}$ & $\begin{array}{l}\mathrm{m}^{2} \\
\mathrm{~m}^{2} / \text { number of } \\
\text { residents }\end{array}$ & $8.438,6(8)$ & $6829,84(8,9)$ & $\begin{array}{c}47557,51(8,9) \\
29,48(9)\end{array}$ & $\begin{array}{l}\text { comparison } \\
5 \mathrm{~m}^{2}-15 \mathrm{~m}^{2} / \text { resident } \\
(1)\end{array}$ \\
\hline & $\begin{array}{l}\text { passive areas (atriums, } \\
\text { private use) }\end{array}$ & $\begin{array}{l}\mathrm{m}^{2} \\
\mathrm{~m}^{2} / \text { number of } \\
\text { residents }\end{array}$ & $\begin{array}{c}2.426,09(8,9) \\
4,47(9)\end{array}$ & $\begin{array}{c}1182,38(8,9) \\
3,46(9)\end{array}$ & $\begin{array}{c}5190(8,9) \\
3,2(9)\end{array}$ & comparison \\
\hline & larger green areas & distance $\mathrm{m}$ & Rožnik hill: 693 (8) & Rožnik hill: 985 (8) & Rožnik hill: 1277 (8) & comparison \\
\hline & & & CELOVŠKI DVORI & MESARSKA & VS4 - BONIFACIJA & \\
\hline & INDICATOR & $\begin{array}{c}\text { TYPE OF } \\
\text { MEASUREMENT }\end{array}$ & & VALUE & & $\begin{array}{l}\text { REFERENCE } \\
\text { VALUE }\end{array}$ \\
\hline \multirow{7}{*}{ 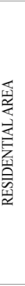 } & surface area & $\mathrm{m}^{2}$ & $24.364,42(8)$ & $30.299,44(8)$ & $83.744,53(8)$ & comparison \\
\hline & $\begin{array}{l}\text { number of all residential } \\
\text { units }\end{array}$ & number & $833^{*}$ & $688^{*}$ & $904 *$ & comparison \\
\hline & $\begin{array}{l}\text { number of occupied } \\
\text { apartments }\end{array}$ & number & $190 *$ & $396^{*}$ & $759 *$ & comparison \\
\hline & number of residents & number & $526^{*}$ & $799^{*}$ & $1613^{*}$ & comparison \\
\hline & building height & $\begin{array}{l}\mathrm{gf}+\mathrm{x} \text { (ground floor } \\
+\mathrm{x} \text { floors }+ \\
\text { mansard) }\end{array}$ & $g f+9(11)$ & $\begin{array}{c}\mathrm{gf}+3+2 \mathrm{M}, \mathrm{gf}+6 \\
(12)\end{array}$ & $g f+4, g f+10(T)$ & comparison \\
\hline & FSI- floor space index & $\begin{array}{l}\text { gross floor surface } \\
\text { area/ site surface } \\
\text { area }\end{array}$ & $2,79(11)$ & $1,8(12)$ & $0,68(\mathrm{~T}, 8,9)$ & $\begin{array}{l}\text { depending on the } \\
\text { number of floors ( } 3 \text { ) }\end{array}$ \\
\hline & site coverage & $\begin{array}{l}\text { gross groundfloor } \\
\text { surface area/ site } \\
\text { surface area }\end{array}$ & $0,27(11)$ & $0,3(9)$ & $0,20(\mathrm{~T}, 8,9)$ & comparison \\
\hline \multirow{4}{*}{ 畜 } & grocery shop & $\begin{array}{l}\text { shop/ number of } \\
\text { residents } \\
\text { distance } \mathrm{m}\end{array}$ & $\begin{array}{c}0(\mathrm{~T}) \\
360(8)\end{array}$ & $\begin{array}{c}2(\mathrm{~T}) \\
\text { across the street }(\mathrm{T})\end{array}$ & $\begin{array}{c}1(\mathrm{~T}) \\
0\end{array}$ & $\begin{array}{l}\text { average } \\
\text { average }\end{array}$ \\
\hline & children's playgrounds & $\begin{array}{l}\mathrm{m}^{2} / \text { number of } \\
\text { residents }\end{array}$ & $0,67(9)$ & $0,7(9)$ & $1,16(9)$ & $\begin{array}{l}2,4-4,8 \mathrm{~m}^{2} / \text { resident } \\
\text { (1) or } 4,0-13,0 \\
\mathrm{~m}^{2} / \text { resident (3) }\end{array}$ \\
\hline & sports facilities & $\begin{array}{l}\mathrm{m}^{2} / \text { number of } \\
\text { residents }\end{array}$ & $0,75(9)$ & $0,2(9)$ & $0,41(9)$ & $\begin{array}{l}2,88 \mathrm{~m}^{2} / \text { resident (3) - } \\
3 \mathrm{~m}^{2} / \text { resident (1) }\end{array}$ \\
\hline & car park areas & $\begin{array}{l}\text { number of parking } \\
\text { places/apartment }\end{array}$ & $2(11)$ & $2(9,12)$ & 0.9 & $\begin{array}{l}1,5 \text { parking spaces/ } \\
\text { apartment ( } 2 \text { ) }\end{array}$ \\
\hline \multirow{4}{*}{  } & all open areas & $\mathrm{m}^{2}$ & $14284,42(8,9)$ & $20959,14(8)$ & $66946,51(8)$ & comparison \\
\hline & $\begin{array}{l}\text { functional areas } \\
\text { (excluding private } \\
\text { groundfloor atrium } \\
\text { gardens, roads and } \\
\text { external car park areas) }\end{array}$ & $\begin{array}{l}\mathrm{m}^{2} \\
\mathrm{~m}^{2} / \text { number of } \\
\text { residents }\end{array}$ & $12976,17(8,9)$ & $14849,14(9)$ & $47557,51(8,9)$ & $\begin{array}{l}\text { comparison } \\
5 \mathrm{~m}^{2}-15 \mathrm{~m}^{2} / \text { resident } \\
(1),\end{array}$ \\
\hline & $\begin{array}{l}\text { passive areas (atriums, } \\
\text { private use) }\end{array}$ & $\begin{array}{l}\mathrm{m}^{2} \\
\mathrm{~m}^{2} / \text { number of } \\
\text { residents }\end{array}$ & $\begin{array}{c}1308,25(8) \\
2,49(9)\end{array}$ & $\begin{array}{c}6110(8, S) \\
7,65(9)\end{array}$ & $\begin{array}{c}5190(8,9) \\
3,2(9)\end{array}$ & comparison \\
\hline & larger green areas & distance $\mathrm{m}$ & $\begin{array}{l}\text { Rožnik hill: } 1204 \mathrm{~m} \\
\text { (8) }\end{array}$ & Golovec hill: 370 (8) & Rožnik hill: 1277 (8) & comparison \\
\hline
\end{tabular}

(1) Urbanistični kriteriji, normativi in standardi za prostorsko planiranje in urbanistično načrtovanje $\mathrm{v}$ Republiki Sloveniji, Zelene površine $v$ mestu, Urbanistični inštitut RS: Ljubljana, 1995. 
(2) Uradni list Republike Slovenije, št. 1/2011, Pravilnik o minimalnih tehničnih zahtevah za graditev stanovanjskih stavb in stanovanj, 2011.

(3) Pogačnik, A., Urbanistično planiranje, Univerza v Ljubljani, Fakulteta za gradbeništvo in geodezijo: Ljubljana, pp. 139-140, 1999.

(4) Strateški prostorski načrt Mestne občine Ljubljana, Urbanistični inštitut Republike Slovenije: Ljubljana, 2009.

(5) Jernejec, Kompleksno pojmovanje okolja človekovega prebivanja in dela stanovanjsko okolje, Urbanistični inštitut Republike Slovenije: Ljubljana, 1974.

(6) Bolha, J., Finančna analiza projekta Nova Grbina pred in po gradnji, graduation thesis, Univerza v Ljubljani, FGG, 2007.

(7) Access to local Civic Office, 2012.

(8) Measurement, Auto Cad, dtb500, 2012.

(9) Calculation, 2012.

(10) studio Linear d.o.o., Vodilna mapa. Stanovanjska zazidava Vič, večstanovanjski objekti “A”, “B”, “ $C$ ”, “ $D$ ” in "E”. Območje urejanja VS 3/2-1-Vič, morfološka enota 1A/2, ordered details, 2006.

(11) Uradni list RS št.: 11/2006, Občinski lokacijski načrt za del območja urejanja ŠO1/2 Šiška, 2006. http://www.uradni-list.si/

(12) Data from: Četrtna skupnost Trnovo, Devinska ulica 1B, 1115 Ljubljana, 2012.

(13) Prenova mesta: Metodološka orodja za določanje in vrednotenje prednostnih območij in tipov prenove. CRP Konkurenčnost Slovenije 2006-2013, Urbanistični inštitut Republike Slovenije, Ljubljana, 2007.

(T) Fieldwork data. (S) Web sourced data. *SURS.

Comparison between estates.

Average of all estates.

opportunities, shown by the fact that a large number of play-related activities take place outside of designated playgrounds. This 'experiential value' is provided by landscape features with unrestricted tree growth, bushes, vast quantities of grassy areas and a modulated terrain feature. Many trees found in the newer housing complexes do not reach their optimal sizes, causing that all new playgrounds show poor or nonexistent sun shelter solutions, which is a result of planning green areas on the roofs of underground car parks. The thickness of the soil layer in such green roof constructions does not support trees and designing park features within new residential complexes (Gazvoda [18]).

Apart from the size and quality of playgrounds, an indicator showing how well a residential estate is equipped, is also the availability of car parking areas. These are adequately provided in the case of all selected residential areas except Bonifacija estate - VS4, which does not meet present-day needs for car parking. The newer housing complexes offer a number of car parks planned according to the average current needs - 1.5 parking spaces per residential unit, a number much greater than it used to be years ago [19]. Realistically speaking however, some Slovene families happen to own up to three vehicles nowadays (Plut [20]). All older estates included in the first methodological phase of research, face a big challenge of providing car parking areas, as the needs have changed since they were being planned and built. Even VS4 estate does not include an adequate amount of car parking facilities compared to the reference value, despite the fact that underground parking garages were planned as part of the original design. 
Using the total surface area of open spaces as the baseline data, the information about the active-use and passive-use areas was calculated. Activeuse surfaces are the open areas excluding private areas, car parks and streets, while passive-use areas demonstrate the number of private areas. Active-use green areas are defined as the ones substantially contributing to the overall quality of life and are equally accessible to all residents. However, even in this case the numbers do not illustrate the actual situation. The largest amount of active-use open spaces are found in the case of Mesarska $\left(14849.14 \mathrm{~m}^{2}\right)$, even though in reality this residential area offers the lowest quantity of experientially diverse places; the spaces between the apartment blocks are fully paved and the only greenery available plays a single role of visual barrier of ground level gardens, hence not adding any useful value to the open space environment. Looking at the surface area data, Viška Sončava and Celovški Dvori residential complexes show a decent amount of functional areas; however in fact these are all pedestrian areas and tartan-covered playgrounds, with no greenery and experiential value. The largest proportion of functional open and green areas can be found in Bonifacija estate (29.48 $\mathrm{m}^{2}$ per resident).

The collected and calculated data was interpreted with the help of observing users in space. The observation results have been graphically presented and illustrate the uses of space filtered by the category 'activities'. Two categories describing activities related to spending time outdoors, divided to 'active use' and 'passive use', demonstrate how well a place serves its use. Activities included in these two categories include child's play, playful running and trampoline jumping ('active' use'), looking after children while they play, sitting on a bench, chatting ('passive use'), etc. Apart from activities representing the active and passive use of space, the graphical presentation also shows the uses related to children actively spending their time in space, achieved by filtering the data using categories 'activities' and 'age groups'. This is shown in a comparative analysis of two residential areas, most dissimilar in terms of the quantity of active-use open spaces and the amount of possibilities for spending time in space: Mesarska and Bonifacija - VS4 residential areas, illustrating the category of activity 'active in space', filtered to show age groups 1 and 2 (up to 12 years) in relation to other activities observed in the same time (fig. 1).

This comparative analysis supports the initial research thesis, stating that poor programme equipment and insufficient amount of open spaces lead to low quality spatial uses. Children from VS4 residential area spend their time in the open spaces in a dispersed pattern, resulting from the playground equipment being equally distributed throughout the estate; whereby the children's activities are not restricted to playgrounds, proving the successful programme planning and attractive qualities of residential landscapes. On the other hand, the Mesarska estate children's activities are restricted to only one playground, already critically too small regarding the play area-to-resident ratio; and it might become even more overloaded by users when new residents start moving into the yet uninhabited properties. The rest of Mesarska open spaces, as expected, reflect a transit character, as there is no programme equipment in the spaces between apartment blocks. 

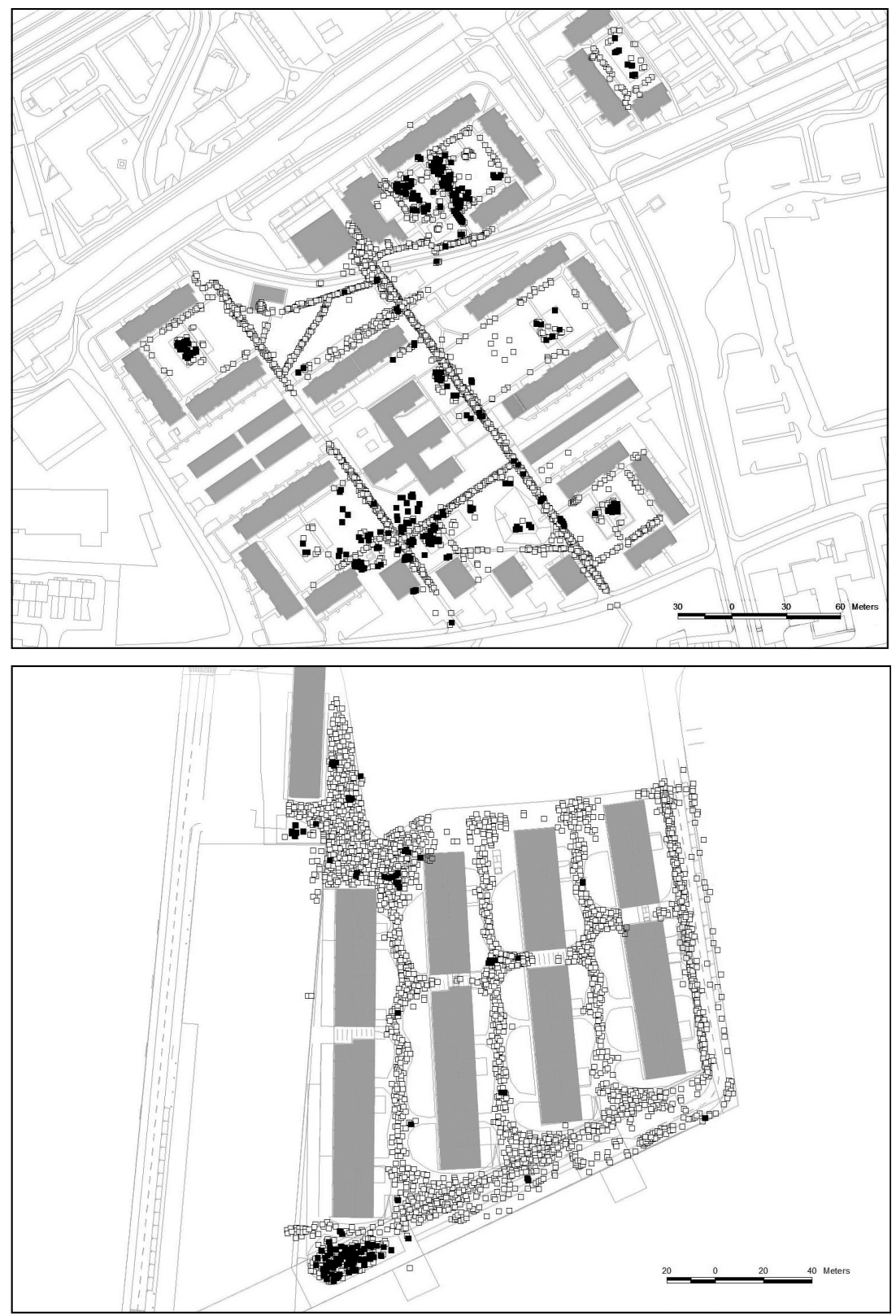

Figure 1: Results of observations and behavioural mapping in VS4 estate (above) and Mesarska residential complex (below).

The method of observations and behavioural mapping provides an additional insight into the quality of selected residential open spaces. The active and 
passive uses are not equally distributed in Nova Grbina example, as it is the case in Bonifacija; even though programme equipment is equally dispersed throughout the space. There are namely four identical playgrounds for the youngest children, located in Nova Grbina, which can be questionable, as there were only $12 \%$ of children under the age of 5 living in the estate according to the statistical data from 2011 (SURS [21]). Out of the four playgrounds, only two were found being used, while one of them was found completely empty during the course of all observation sessions. The majority of active and passive uses in the open spaces of Nova Grbina were concentrated in the grassy area, furnished with some pieces of play equipment, outside of the designated playgrounds. Older children and senior citizens were observed very rarely in these spaces, since the space itself does not offer many options for spending time outdoors; which leads to an assumption, that urban furniture does not guarantee an effective open space. A similar conclusion can be drawn from the results of observation in Viška Sončava, where individual play equipment pieces were located between apartment blocks. There playgrounds were observed being used by children, accompanied by elderly people; while one playground was observed to be always empty. Transit activities were recorded in largest quantities in spaces between apartment blocks of Viška Sončava - a fact which suggests that there are many more residents living in this area than there are open spaces at their disposal, even though table figures show an adequate amount of usable surfaces per resident. This implies, that the number of residents had increased substantially since the last census two years previous to the survey, while on the other hand the open spaces similarly to the example of Nova Grbina suffers a shortage of equipment appropriate for other age groups, especially senior citizens. Are however an example of Celovški Dvori residential complex, where observation results have to be analysed with great caution. At first glance this complex actually seems extremely dynamic and rich in uses; however the results must be paired with the social profile of residents. Due to the social status of a part of the estate, the prevailing residents have a low level of education and are economically disadvantaged; additionally there is a high concentration of foreign residents (Mladenovič [22]). For this reason, many new questions are raised, which cannot fully be answered using simply the observation method. Some of these questions are: 'How do residents feel living in an estate, where they had not chosen themselves; does a mixture of nationalities cause residents to form groups and avoid developing good neighbourly relations; what is the perception of security like; do people identify with the area; how inviting and useful the residential open spaces really are, etc'.

\section{Conclusions and research perspectives}

At the beginning of the research, the qualitative and quantitative differences between old and new residential estates were quantified and verified: the new ones are smaller in total surface area, they are planned to accommodate a large density of residents compared to the old estates; the open space programme usually includes only children's playgrounds, which are inadequate according to 
general recommendations. Programmes for older children and other age group residents are very rarely provided. The final appearance of the new collective developments is a result of property shortage and unavailability of space in the past, as well as a lack of spatial norms, guidelines and regulations, which would commit the developers to adequate dimensioning, equipping and design of residential open spaces (Simoneti and Vertelj Nared [3]). The basis of this research is a comparative study between the old and the new residential estates, however all older estates are not best quality examples; the first post-war collective developments aimed to address the critical accommodation shortage. In addition, lifestyles have changed through time, the economy has improved, the standard of living has increased and people's expectations have risen and changed. What was in the past perceived as an ideal living environment, has with time been given a new connotation, as some estates began to be linked to criminal activity, social exclusion, unemployment, ethnical minorities, etc. In the context of increasing challenges of large residential estates throughout Europe, much attention is given to their renewal and regeneration, aimed to meet the needs of the new user profile (Kempen et al. [23]). These challenges however do not negate the hypothesis that their open spaces are of higher quality than in the new developments; they merely show a possibility that these challenges might cause residents to see their estates in a different way than originally intended.

The method of observations and behavioural mapping, used in the second research stage proved the hypothesis that poor equipment and the lack of open areas lead to a reduced variety of spatial uses and do not support a healthy lifestyle. This is shown by a comparative study of observation results of Bonifacija estate and the newer developments; most evidently in the case of Mesarska residential complex (fig. 1). Nonetheless, the observation results show only a partial image, as there are certain questions that remain unanswered in the background of recorded activities. Being mere slices of the continuity of action, observation results must be understood as approximation to the actual state of open space functionality. A part of uncertainty remains due to activities performed outside of observation periods. Additionally, some of the observed users may be external visitors and not necessarily local residents. And finally, the mere emergence of users in a certain place does not guarantee its success; the questions not addressed by the observation method are in particular the general welfare and comfort of users, the ability to identify with the space and the feeling of security. Observations fail to record the users which find no appropriate possibilities of spending time in the open space; therefore it is also questionable, how well a place accommodates different age groups. Due to a lack of open areas in new residential developments, the observations may even lead to wrong impressions, because a small place fills up quickly and may seem appealing and generally thriving, while in reality it may be a case of overloading a spatial capacity, discouraging other potential users from approaching.

In order to comprehensively interpret the success of residential landscapes, it is essential to connect the physical, social and symbolic spatial variables, which reveal the invisible links between the structure, behaviour and perception. The follow-up research will therefore adopt the method of questionnaires, which will 
be designed to collect the impressions and opinions of local residents. The survey is crucial for addressing the question about how well do people live in it and which life-styles they develop in response to spatial opportunities. Ogrin indicates that only the local residents' opinion survey can provide those answers (Ogrin [24]), which is further justified by the fact that people's perceptions change with generations (Mandič and Cirman [25]).

\section{References}

[1] Simoneti, M., Kranjc, U., Vidic, L., POT, največja načrtovana javna zelena površina v Ljubljani, Trajekt, zavod za prostorsko kulturo: Ljubljana, pp. 50-51, 2008.

[2] Ward Thompson, C., Travlou, P., Playful nature, What makes the difference between some people going outside and others not? (Chapter 3) Open Space: People Space, Taylor \& Francis Group: Abingdon, UK, pp. 23-37, 2007.

[3] Simoneti, M., Vertelj Nared P., Odprte površine ob stanovanjskih objektih - zapostavljen vidik kakovosti bivanja, Proc. Of the $1^{\text {st }}$ Conf. On Stanovanjske krajine, trendi in perspektive, Biotehniška fakulteta, oddelek za krajinsko arhitekturo: Ljubljana, pp. 17-24, 2006.

[4] Gazvoda D., Vpliv programa oziroma strukture stanovanj ter tehničnih omejitev gradnje na oblikovanje odprtega prostora naselij, Proc. Of the $1^{\text {st }}$ Conf. On Stanovanjske krajine, trendi in perspektive, Biotehniška fakulteta, oddelek za krajinsko arhitekturo: Ljubljana, pp. 42-47, 2006.

[5] Mihelič, B. Urbanistični razvoj Ljubljane, TOZD Založba: Ljubljana, pp. 51-61, 1983.

[6] Rebernik, D., Urbano-geografsko proučevanje blokovskih stanovanjskih sosesk kot element urbanističnega planiranja, Dela, 18, pp. 463-475, 2002.

[7] World Health Organization (WHO), Urban population growth, http://www.who.int/gho/urban_health/situation_trends/urban_population_gr owth_text/en/

[8] Philomena, M., Product Policy and Indoor Air Quality, Background document, Indoor sources and health effects: background information and ways to go, Directorate general for the Environment of the Belgian federal Public service of Health, Belgian Presidency of the Council of the European Union: Brussels, 2010.

[9] Indoor Air Facts No. 4 (revised), Sick Building Syndrome, Research and Development, MD-56, Environmental Protection Agency, pp. 1-4, 1991.

[10] Artnik, B., Bajt M., Bilban M., Borovničar A., Brguljan Hitij J., Djomba J. K., Fras Z., Hlastan Ribič C., Jeriček Klanšek H., Kelšin N., Kofol Bric T., Kolšek M., Koprivnikar H., Korošec A., Košnik M., Kranjc M., Lovrečič B., Lovrečič M., Maučec Zakotnik J., Orožen K., Paulin S., Šelb Šemerl J., Šerona A., Tomšič S., Zaletel J., Zaletel M., Zdravje in vedenjski slog prebivalcev Slovenije. Trendi v raziskavah CINDI 2001 - $2004-2008$, Inštitut za varovanje zdravja Republike Slovenije: Ljubljana, pp. V-VI, 2012. 
[11] Uradni list Republike Slovenije št. 76/2004, Strategija prostorskega razvoja Slovenije, 2004. http://www.uradni-list.si/

[12] The $1^{\text {st }}$ Conf. On Stanovanjske krajine, trendi in perspektive, Biotehniška fakulteta, oddelek za krajinsko arhitekturo: Ljubljana, 2006.

[13] Dimitrovska Andrews, K., Orodja za usmerjanje in nadzor urbanih oblik, Urbanistični inštitut Republie Slovenije: Ljubljana, pp. 79, 2011.

[14] Zaletel-Krajgelj, L., Eržen, I., Premik, M., Uvod v javno zdravje, Univerza v Ljubljani, Medicinska fakulteta, Katedra za javno zdravje: Ljubljana, pp. 82-83, 2007.

[15] Goličnik, B., Ward Thompson, C., Opazovanje in vedenjski zemljevidi. Metoda raziskovanja javnega odprtega prostora v mestu. Urbani izziv, 12 (1), pp. 82-89, 2002.

[16] Uradni list Republike Slovenije št. 76/2004, Strategija prostorskega razvoja Slovenije, pp. 31-35, 2004. http://www.uradni-list.si/

[17] Uradni list Republike Slovenije, št. 122/2004, Uredba o prostorskem redu Slovenije, 2004. http://www.uradni-list.si/

[18] Gazvoda, D. Vloga in pomen zelenega prostora v novejših slovenskih stanovanjskih soseskah. Urbani izziv, 12 (2), pp. 35-42, 2001.

[19] Uradni list Republike Slovenije, št. 1/2011, Pravilnik o minimalnih tehničnih zahtevah za graditev stanovanjskih stavb in stanovanj, 2011. http://www.uradni-list.si/

[20] Plut, D., Ljubljana in izzivi sonaravnega razvoja, K-tisk: Ljubljana, p. 78, 2007.

[21] Statistični urad Republike Slovenije (SURS), Statistical office of the Republic of slovenia, ordered details, 2011.

[22] Mladenovič, L., Kriteriji za trajnostno načrtovanje in gradnjo območij z visoko gostoto poselitve, Doctoral dissertation, Univerza v Ljubljani, Fakulteta za arhitekturo: Ljubljana, pp. 101-102, 2011.

[23] Kempen, R., Murie, A., Knorr-Siedow, T., Tosics, T., Sendi, R., Černič Mali, B., Filipović, M., Boškić, R., RESTATE, Regeneracija velikih stanovanjskih sosesk $v$ Evropi. Priročnik za boljšo prakso. Urbanistični inštitut Republike Slovenije: Ljubljana, p. 15, 2007.

[24] Ogrin, D., Krajinska arhitektura, Univerza v Ljubljani, oddelek za krajinsko arhitekturo: Ljubljana, p. 174, 2010.

[25] Mandič, S., Cirman, A., Stanovanje v Sloveniji 2005, Fakulteta za družbene vede: Ljubljana, pp. 182-184, 2006. 